\title{
Forestry education in Russia
}

\author{
by Victor K. Teplyakov ${ }^{1}$
}

A general overview of Russian forests and school system plus a brief history of Russian forestry education are presented.
L'auteur décrit de façon générale les forêts et le système d'éducation en Russie, et présente un bref historique de la formation en foresterie en Russie.

\section{Introduction}

The area of Russia is 1,706.9 million hectares. Forests and cultivated lands comprise less than two-thirds of the total territory with the rest consisting of populated areas, industries, transportation systems, mountains, polar tundra, glaciers, and water bodies.

Mean January temperatures vary from $0^{\circ} \mathrm{C}$ at the Black Sea to $-40^{\circ} \mathrm{C}$ in Yakutiya, the site of the Russian record low temperature (about $-73^{\circ} \mathrm{C}$ ). The mean July temperature ranges from 10 to $25^{\circ} \mathrm{C}$. Much of the country has inadequate precipitation to support forests.

Forests cover $39 \%$ of Russian territory. The total forested area was estimated by a 1988 national inventory at 1086 million ha, and the total growing stock was 82 billion $\mathrm{m}^{3}$. The area is about equal to that of the USA, Canada, Finland, Sweden, and Norway combined.

Russia contains $22.7 \%$ of the world's growing stock $^{1}$ (Lesa Rossii 1992). Almost 80 per cent of the total growing stock is coniferous forest, representing one-half of the world volume. Since the USSR ${ }^{2}$ collapsed, about $25 \%$ of its territory, $50 \%$ of its population, and only $4 \%$ of its forests are outside of Russia in other republics and states. Old age and low site quality lead to very low mean annual timber increment of $1.2 \mathrm{~m}^{3} \mathrm{ha}^{-1}$, and the mean growing stock of all forests is $114 \mathrm{~m}^{3} \mathrm{ha}^{-1}$.

For a long time the country's development has been based on the extensive use of production factors: the use of new resources, materials, finances, labour, and the construction of more factories. Only 16 per cent of the total resident population lives in Siberia and the Far East, where over 75 per cent of the timber resources are located.

Forestry's share in the gross domestic product is about 0.1 per cent, and the state employment in the silviculture sector of the economy comprises 236,000 people, that is 0.4 per cent of the total employees in Russia ${ }^{3}$. Until recently, Russia harvested about 300 million $\mathrm{m}^{3}$ of timber annually, but in 1992 only about 200 million $\mathrm{m}^{3}$ were harvested.

Activity to protect and control forests against damage is increasing each year. In 1980 biological control was carried out on about 390 million ha, and when combined with chemical methods over half a million ha. By 1990, the area under biological control was increased by about 100 million ha and chemical con-

\footnotetext{
*Associate Professor of Forest Management: Moscow State Forestry University; Deputy Head Scientific Department, Federal Forestry Service of Russia.

This paper was presented at the 17th session of the FAO Advisory Committee on Forestry Education in Bangkok, Thailand.

${ }^{1}$ Federal Forestry Service of Russia, Novocheriomushkinskaya 69, Moscow 117877, Russia.
}

trol decreased. Aerial forest fire protection was conducted on about $75 \%$ of the total forest land.

Since 1916, some 72 National Reserves covering about 20 million ha of national lands, and 24 National Parks with a total area of about 2.5 million ha have been created ${ }^{4}$.

\section{General Education and Labour Forces}

The Russian educational system was reorganized during the 1980s. Starting at 6 (so-called "Zero class/grade") or 7 (the first class/grade), children receive 9 (8) years of comprehensive mandatory, state-supported schooling. Comprehensive school is divided into 3 years of primary, and 6 years of secondary school. At primary school, children gain a basic knowledge of reading, writing, counting, nature observation, and other subjects. At the secondary level, pupils study history, algebra, literature, geography, physics, chemistry, biology, drawing, foreign languages, and other disciplines.

After finishing comprehensive school, students can choose to go directly into the labour force, or continue their education by taking short-term (from several months to 1 year) courses in one of many businesses, or continue their education at secondary-modern school (3 more years), vocational school or college (3-4 more years). Secondary modern school, vocational school and college give an opportunity to continue education at university (institute, academy).

To enter college or university one must pass exams. Usually, it takes from 5 to 7 years to obtain a diploma of engineer or MS, and 3 more years after graduating from the university to get a Ph.D. degree.

For a long time before the 1930 s, all forest regeneration and other forest work were done by seasonal workers (peasants of nearby villages, mostly women and children). The right of land temporal use for crops, hay, grazing or deadwood picking, was used as a payment for the job. But a user was obligated to regenerate the forest and treat young stands on the rented lands.

After establishing state forestry enterprises, and especially in 1947, when Russia began to invest in field forest stations,

${ }^{1}$ Lesa Rossii. 1992. Moscow: Komitet po lesu, p.4. (Forests of Russia. Issue of the Forestry Committee of Russia).

${ }^{2}$ Teplyakov, V.K. 1989. Land Use and Forests Outputs in the Soviet Union/ Land use for agriculture, forestry and rural development: pp. 323-335. In M.C. Witby and P.J. Dawson, Eds. The Proceedings of the 20th Symposium of European Association of Agricultural Economics (EAAE). Newcastle upon Tyne, England, July 5-6, 1989. University of Newcastle upon Tyne, 1990.

${ }^{3}$ Narodnoye khoziaistvo RSFSR v 1989 g. 1990. Moskva: Finansy i Statistika. (National Economy of Russia in 1989. Statistical yearbook).

${ }^{4}$ Okhrana okruzhayushchei sredy i ratsional'nœe ispol'zovanie prirodnykh resursov v SSSR: Statisticheskiy sbornik. 1989. Moskva, Finansy i Statistika (Statistical Handbook on Environmental Protection), p. 119-127. Russian Forests (in press). 
many permanent workers appeared in national forestry. The tractor operator became a main specialist in silviculture, forest regeneration and afforestation. While in 1960 over 57,000 people worked in forestry (planting, pest control, timber management, etc.) for which national budget money was used, and more than 112,000 people worked for profit (pre-commercial cutting, thinning, logging and other industrial jobs), in 1966 permanent workers comprised respectively 114,000 and $175,000^{5}$, and in the 1990 s 166,000 people. About $15,000-20,000$ people were trained as qualified forest workers annually. Now only 2,200 qualified workers are trained annually for forestry. There are 22 consulting locations scattered across Russia for this purpose.

\section{Vocational Schools and Forestry Colleges}

In Russia, professional training of foresters began in 1800, when a "forstmeister class" was established within the Navy Cadet Corps in St. Peterburg. According to "Forest Regulations" (1802), Article 19, the Forestry Department was entrusted to establish forestry schools "for educating and teaching people in forestry sciences". The Forestry Institute was founded in 1803 in Tsarskoye Selo (Tsar Village) near St. Peterburg. A second forestry school was established in Kozel'sk (Kaluga province) in 1805 it was the Kaluzhskiy Forestry Institute ${ }^{6}$.

The first vocational forestry school in Russia - Lisino Huntsmen School - was established in a supplementary facility of the forest belonging to the St. Peterburg Forestry Institute. It was established by Duke E.F. Kankrin in 1834 for training foresters. The training period was 2-4 years. Applicants generally were less than 18 years old. The curriculum contained silvics, drawing, arithmetics and counting, Russian grammar, geometry and trigonometry basics. In the 1840 s, four more huntsmen schools were organized in other provinces. In 1869, Lisino Huntsmen School was reorganized into Lisono Forestry School. By 1886 the Lisono Forestry School had trained about 1,300 forest specialists. Because of educational system reorganization all the huntsmen and forestry schools were closed by 1887 .

In 1888,10 vocational forestry schools were founded for the lower forestry education. Every school had 15 pupils. In 1917, the number of vocational forestry schools increased to 39 . These schools provided 2 years training predominantly in practical work for about 450 students.

Secondary forestry education was established in 1925-1930 on the basis of the former vocational schools. In 1928, there were five forestry secondary schools (250 pupils) in Russia, in the middle of the $1950 \mathrm{~s}-16$ (1,140 pupils), at the beginning of the $1960 \mathrm{~s}-34$ (2,050 pupils), ${ }^{7}$ and in $1993-3$ schools (2,950 pupils). Forestry schools offer basic knowledge in forestry and forest industry, field jobs, forestry machines. The forestry program includes intensive courses in tree marking, thinning, felling, and other worker skills.

Forestry colleges ("tekhnikum") were established as part of the forestry educational system reorganization in the 1920s. In 1965 , forestry colleges enrolled over 10,000 students, and annual attendance was 3,100 day-time and about 1,900 extra-

\footnotetext{
${ }^{5}$ Lesnoye Khoziaystvo Rossii. 1968. Moscow: Lesnaya Promyshlennost. (Russian Forestry).

${ }^{6}$ Beylin, Isaak G. 1962. Ocherki po istorii lesnykh obshestv dorevolutsionnoy Rossii. Moscow: Goslesbumizdat (Sketches on history of the Russian forest societies before revolution 1917), p. 19-20.

${ }^{7}$ See footnote 5 .
}

mural students. Now there are 23 forestry colleges with 10,370 full-time and 6,100 extra-mural students in Russia, and annual attendence is 4,940 people.

Forestry colleges offer basic knowledge in forestry, silviculture, forest ecology, forest estimation, tree planting, pest control, felling, sawing, forestry machine operating, and other technical skills.

Eighteen of 23 colleges have their own forests with a total forest land area of about a half million ha. These forests are dedicated to forest specialist training through practical job experience and skills. Also, college forests maintain a variety of permanent and other research sampling plots. For example, in the forest of Lisino college some permanent experimental plots have had more than 120 years of observations. This gives the students a chance to be more familiar with research methods used and to see stands under different treatment and timber management practices. While most of the plots are designed for research purposes, they are often used for demonstration of natural understory regeneration systems, for site type evaluation, stand measurements, cruiser training, etc.

Teachers for secondary forestry schools and forestry colleges are required to have at least one level of education higher than that they are going to teach. To obtain the position of teacher, they must take additional courses at an educational university to become more familiar with educational technology. Usually, every 5 years, teachers should take courses to update their professional knowledge and teaching skills. They also participate in 1-3 day seminars and workshops dealing with teachers' interests.

\section{Years of Russian Higher Forestry Education}

In 1993, Russian higher forestry education celebrated its 190th anniversary. As stated earlier, the first Forestry Institute was founded in 1803 in Tsarskoye Selo. In 1803 and 1804 only 10 students were appointed annually. Institute staff included a supervisor, forest land surveyor, drawer, and translator.

In 1805 , Kaluga Forestry Institute was established in Kozel'sk for 30 students. The goal of this Institute was "to translate forestry books for promotion and education of those, who were unable to read foreign books and could not come to the Institute".

In 1808 , the Forestry Institute was opened in St. Peterburg. In 1811, the Tsarskoye Selo Institute was joined to this Institute. In 1813, Kaluga Forestry Institute was moved into Peterburg, and one St. Peterburg Forestry Institute was formed. According to the St. Peterburg Forestry Institute Regulations of 1829 , the curriculum was designed for 6 years of training. There were 13 professors and staff and 108 students. The curriculum included arithmetics, algebra, geometry, trigonometry, geodesy, forestry (planting, cutting, management), natural history, forest botany, physics, chemistry, forest statistics, forest regulations (laws), religion classes, history, geography, Russian and German languages, counting, calligraphy, drawing, "shooting and huntsmen arts", music and dancing 8 .

In 1863 the St. Peterburg Forestry Institute obtained a new status - the St. Peterburg Forestry Academy. To enter the Academy, applicants had to finish a gymnasium (secondary modern school) or university. Two years educational process was

\footnotetext{
${ }^{8}$ See footnote 6.
} 
divided into theoretical studies (about $50 \%$ of time) and practical work in the Lisino forest.

Since 1902, practical aspects of training in forestry have been stressed. More disciplines dealing with the forest were included in the curriculum, some disciplines were separated, for example, forest constructions and engineering art, forest management and forest regulations, etc. Before graduating, all forestry students had to carry out specially designed qualification work. This was a job in the state run forests.

By 1917 , only 4,200 professional foresters had been graduated from the Peterburg Forestry Institute, because the annual number of applicants did not exceed 250. Now the Academy has forestry, forest economics, chemical technology of wood, mechanical technology of wood, wood mechanics, and forest engineering day-time faculties (colleges), and other faculties, laboratories and centers. The number of students is about $10,000^{9}$

Since 1917, the Academy has trained over 50,000 forest specialists including such well-known individuals as A.F. Rudzsky, D.M. Kravchinsky, G.F. Morozov, M.M. Orlov, M.E. Tkachenko, V.I. Sukachev and many other people who were students and then professors of this Institute.

In Moscow, the first forestry institution was established in 1865. It was Petrovsky Agricultural and Forestry Academy (now Timiriazev Agricultural Academy). The Moscow Forest Engineering Institute (now Moscow State Forestry University) was established in 1919 and became the country's first higher education institution training forest engineers.

Today forestry, timber industry, and pulp and paper industry specialists are trained in 38 institutions, including St. Peterburg Forestry Academy, Moscow State Forestry University, 4 forest engineering, 9 polytechnic, 7 technological, and 11 agricultural institutes, academies and universities and 13 of them are in forestry. Specialists for forest-related fields are trained in 7 specialities enlarged in 1988, to more than 15 specializations. They are: forestry, urban forestry and landscape gardening, forest engineering, wood treatment technology, chemical and mechanical technology of wood and wood materials, forestry machines and logging equipment, automation of technological processes and works, economy and management of chemical and forest industries ${ }^{10}$.

The structure of a forestry institute and the curriculum of the forestry faculty can be exemplified by the Moscow State Forestry University (MSFU) ${ }^{11}$. For a long time the MSFU was a leading forestry institute in the USSR. Over 80 per cent of all textbooks and manuals fundamental for higher forestry and forest-engineering education in the former USSR have been composed by professors and scientific staff of the MSFU (at that time Moscow Forest Engineering Institute $)^{12}$. The MSFU has formed therein a number of scientific schools in forestry, and among them the scientific school of Prof. N.P. Anutchin - forest mensuration and forest management, scientific school of Prof.

\footnotetext{
${ }^{9}$ Forest Encyclopedia, 1985. Moscow: Sovetskaya Entsiklopedia, V.1:496. ${ }^{10}$ Oblivin, Alexander N. 1992. Planning and management of training specialists for forestry and forest industry in market economy. In The Proceedings from IUERO International Conference "Integrated Sustainable Multiple-Use Forest Management Under Market System" (September 6-12, 1992. Pushkino, Moscow Region, Russia). Printed in Copenhagen, Denmark, 1992.

${ }^{11}$ Sputnik Pervokursnika, 1993. Moscow: MSFU. 48 p. (A Freshman Guide). ${ }^{12}$ Moscow Forest Engineering Institute. 1985. Moscow: Vneshtorgizdat. $24 \mathrm{p}$.
}

I.S. Melekhov - forestry and forest pyrology, and that of Prof. A.S. Yablokov - forest genetics, Prof. S.S. Sobolev - forest soils and soil erosion, Prof. A.I. Vorontsov — forest entomology and pest control, and several others.

More than 50 Departments comprising over 500 professors and staff of the MSFU train specialists in forestry, timber and wood-working industries, economics, and computer sciences. The MFSU has over 5,000 full-time and about 3,000 extramural students. The University also has a pre-curriculum division and courses for people intending to enter the University. Comprehensive schooling is fundamental and special subjects, and well-designed methods of practical training at forestry enterprises help the students acquire a broad professional outlook, so that the University's graduates are able to become full-fledged managers of modern production.

The basic term of studies in forestry and other professions is 4 years and 10 months. During the first and the second years, students are trained in basic disciplines: general (mathematics, physics, chemistry), technological (geodesy, drawing, computer science, basics of forestry, logging and transportation), biological (botany, dendrology, forest soils, tree physiology) and social (philosophy, history, word culture). An interview on general preparation is held after the third year of studies. Then students are distributed among specialized departments for higher education in a particular area or direction. At the end of their studies, students must prepare and defend their graduation project in the State Examination Commission for obtaining qualification as an engineer in the chosen speciality.

The University operates its own forest, the total area of which is $36,200 \mathrm{ha}$. The forest has eight forest blocks and two basic tree nurseries. The facilities include a well-equipped timber yard, debarking station, sawing, chip-making and furniture-making shops. The forest and facilities allow students to get some practical experience. During the term, students devote up to onethird of their time to professional training at educational and experimental forests, including expeditions into different parts of Russia.

Usually, most forestry university applicants are 18 years old, because they enter the university after finishing regular secondary modern or forestry school. A few applicants are 20-23 years old; they enter the university after military service, finishing forestry college, or some practical work at forest enterprises.

Recently, intensive 3-year training of forestry specialists and engineers has been practised for those who have finished forestry at timber industry colleges (tekhnikum) and have practical experience in forest-related areas. Such students are sent to the university by their employers who pay their salary. Graduates usually return to work for their employers, but in higher positions such as director, main (district) forester, main engineer or main specialist in a specific area (planting, pest control, or harvesting).

\section{Continuing Education}

Teachers (professors) and highly qualified researchers are trained through post-graduate and doctorate programs. For these purposes, a special doctorate department is designed at an institution. Usually, applicants have to be under 35 years old. They have a certain length of service in research and must show the ability to do, independently, the research work. The term of the doctorate program varies from 3 years for full-time students to 4 years for extra-mural students. 
There is almost no difference between the principal approach to doctorate studies in Russia and many other countries. In Russia, a Ph.D. holder can obtain a position of Senior Lecturer, Assistant Professor and Associate Professor in a corresponding area. But, as a rule, to be appointed Professor, one must prepare a second doctorate thesis through a second doctorate program or independently at any institution. At the present time, it has become more common that people obtain their second doctorate as a result of work in a particular field and a number of publications, especially books. The applicant must only pass a public defence at the specialized counsel committee of the university or institute.

A doctorate program is one of several ways to raise the level of professional skill. Generally, the program is good for educational and research institutions. But almost every forestry institute has a specialized department, where foresters can update their knowledge, professional skills or continue their education taking a variety of courses in forestry, mechanization, management, logging operations, etc. Two institutes for raising qualifications were established for these purposes, and there are more for forestry, timber and the pulp and paper industry.

In Moscow State Forestry University there is a department for raising the qualifications of teachers. Teachers from forestry institutions take 3 to 6-month courses to update their knowledge and skills in professional activity and methodology of teaching.

According to the First All-Union (the USSR) Congress of Foresters ${ }^{13}$ documents, an All-Union meeting of the forest-related workers, and higher, secondary, specialized and other educational institutions took place in Moscow in 1991. At this meeting, the Institute for Raising Professional Skills of Forestry Workers was chosen to carry out the project on the continuing

\footnotetext{
${ }^{13}$ Recommendations of All-Union meeting of forest-related workers, and higher, secondary, specialized and other educational institutions, Moscow, April 12-13, 1991, p. 2. (In Russian.)
}

forestry education: kindergarten - secondary modern school — vocational school - college - university. This project is now ongoing.

\section{The Future of Forestry Education in Russia}

Based on an analysis of Russian and foreign experience in forestry education, I propose a possible future for forestry education in Russia:

1. Global changes and growing anthropogenic impact require foresters to better understand the role and functioning of forests, to have deeper knowledge of biological and ecological disciplines, and project the future relationships between forest, nature and society.

2. Futher growth of people's concern in getting more social, cultural and environmental benefits from the forests requires foresters to be better trained in related forestry fields to promote optimal connection between the variety of factors and to implement modern knowledge of science and technology into every day forest practice.

3. The unavoidable involvement of society in forestry decision making and the impact of non-government organizations on forest policy require a greater cross-cultural level of foresters and their communication skills. These will bring more sociological disciplines such as personal and group behaviour, personal communication, and professional writing into forestry curricula.

4. International activity, cooperation and exchange of forestry specialists, knowledge and experience require greater knowledge of foreign languages.

5. Growing understanding of responsibility for the future of forests at local, regional or global levels and for the health of one person or mankind will bring forest ethics to the top position in forestry education. 